\title{
Isolated Growth Hormone Deficiency Type IA Associated with a 45-Kilobase Gene Deletion within the Human Growth Hormone Gene Cluster in an Italian Family
}

\author{
LUCIA GHIZZONI, PHILIPPE DUQUESNOY, TONI TORRESANI, \\ ALESSANDRA VOTTERO, MICHEL GOOSSENS, AND SERGIO BERNASCONI \\ Department of Pediatrics, University of Parma, Italy [L.G., A.V., S.B.]; \\ Service de Biochimie and INSERM, Unit 91, C.H.U. Henri Mondor, Creteil, France [P.D., M.G.]; \\ and Department of Pediatrics, University of Zurich, Switzerland [T.T.]
}

\section{ABSTRACT}

An Italian family with three children presenting with isolated growth hormone $(\mathrm{GH})$ deficiency type IA is described. Restriction endonuclease analysis revealed that the cause of hGH deficiency was a $45-\mathrm{kb}$ gene deletion within the hGH-chorionic somatomammotropin (CS) gene cluster, encompassing the GH-1, CS-L, CS-A, and GH-2 genes. DNA sequence analysis and polymerase chain reaction amplification between two sequences located on each side of the deletion breakpoint accurately identified the deletion breakpoints and indicated that the regulatory sequences located upstream from the TATA box of the mutant CS-B belong to the GH-2 gene. Two of the affected children developed high-titer anti-hGH antibodies after recombinant hGH treatment with secondary growth arrest, whereas the third one maintained normal growth in the presence of very low-titer antibodies. This is the first report of a large deletional mutation within the hGH-CS gene cluster accompanied by phenotypic heterogeneity in terms of growth response and antibody formation in the different patients. (Pediatr Res 36: 654-659, 1994)
Abbreviations
IGHD, idiopathic growth hormone deficiency
GH, growth hormone
$\mathrm{CS}$, chorionic somatomammotropin
(r)-hGH, recombinant hGH
PCR, polymerase chain reaction

$\mathrm{hGH}$ deficiency has a prevalence ranging from 1 in 4000 to 1 in 15000 , and 5-30\% of cases are estimated to be familial $(1,2)$. Several single-gene disorders have been shown to result in IGHD with three different modes of inheritance: autosomal recessive (type I), autosomal dominant (type II), and sex linked (type III) (3). Among type I patients, Illig et al. (4) described a subgroup referred to as IGHD type IA distinguished by the following characteristics: short body length at birth, early growth retardation leading to extreme dwarfism in adulthood, typical facies, strong anabolic response during an initial course of $\mathrm{GH}$ rapidly followed by the appearance of anti-hGH antibodies with growth arrest.

The hGH gene locus expanded during evolution into a cluster of five linked genes located on the long arm of

Received November 8, 1993; accepted March 29, 1994

Correspondence and reprint requests: Lucia Ghizzoni, M.D., Department of Pediatrics, University of Parma, Via Gramsci 14, 43100 Parma, Italy.

Supported in part by a research grant from the Ministero della Ricerca Scientifica e Tecnologica (60\%). chromosome 17 at q22-24 (5). The GH-1 gene codes for normal pituitary $\mathrm{GH}$, whereas $\mathrm{GH}-2$ encodes a peptide that differs from the pituitary $\mathrm{GH}$ by 13 amino acids, which is probably the so-called "human placental GH" (6). The two CS-A and CS-B genes code for the same mature peptide and are responsible for the production of CS by the placenta (7). The CS-L gene shares a high degree of sequence homology with the CS-A and CS-B genes but is expressed at a much lower level than the former genes in term placental tissue.

The molecular basis of type IA IGHD is a homozygous deletion of DNA containing the GH-1 structural gene. Among the cases so far reported, deletions of various size, each including the GH-1 gene, have been described. Most of those characterized are of $6.7 \mathrm{~kb}(70-80 \%)$, and the remainder are of 7.6 and $7.0 \mathrm{~kb}(8,9)$. However, a deletion of $40-\mathrm{kb}$ DNA due to two separate deletions flanking the CS-L gene was detected in two affected siblings presenting with the clinical features of IGHD type IA (10). In addition, a 45-kb gene deletion leaving intact the CS-B gene in three affected boys from a Turk- 
ish family (11) and two Italian siblings (12) has recently been reported.

Although in many patients the complete inborn absence of hGH is associated with immune intolerance to exogenous $\mathrm{hGH}$, considerable variation in anti-hGH antibody formation and growth response is observed not only among different families, but even within families (13). This phenotypic heterogeneity is particularly evident in those cases in which the IGHD results from small deletions within the hGH gene cluster. In fact, to date, each of the patients with large deletions developed anti$\mathrm{hGH}$ antibodies in response to $\mathrm{r}-\mathrm{hGH}$ replacement $(10$ 12).

The present paper describes three affected children presenting with the same $45-\mathrm{kb}$ gene deletion but discordant immune and growth response to r-hGH.

\section{METHODS}

\section{Patients}

An Italian family with three affected children was studied. As shown in the pedigree in Figure 1, the parents of patients VI-2 and VI-3 are third cousins, whereas those of patients V-2 and V-3 do not appear to be related.

Subject V-1. The girl was born in 1988 at term after a normal pregnancy. She developed without any problem and is normal for age.

Patient $\boldsymbol{V}$-2. The second girl was born in 1990 preterm (33 wk gestation) after a pregnancy complicated by several threatened abortions. Her Apgar score at 1 and $5 \mathrm{~min}$ was 5-6. Her birth weight was $1450 \mathrm{~g}$ and length $39 \mathrm{~cm}$. At the age of $4 \mathrm{mo}$, the mother suspected the same disorder as presented in her cousin (patient VI-2), and the baby was referred to our clinic. Her length was $43.7 \mathrm{~cm}(-7 \mathrm{SD}$ score), weight $2890 \mathrm{~g}$, and head circumference $34 \mathrm{~cm}$; she was at Tanner stage I of pubertal development. On physical examination, she had the classic features of IGHD. A month later the patient died of sudden infant death syndrome before we were able to perform any hormonal or genetic study. Therefore, it can only be inferred that the baby was affected by IGHD due to hGH gene deletion.

Patient V-3. The child, a girl, was born in 1991 after a pregnancy complicated by premature labor but otherwise uneventful. Her main clinical and hormonal characteris-

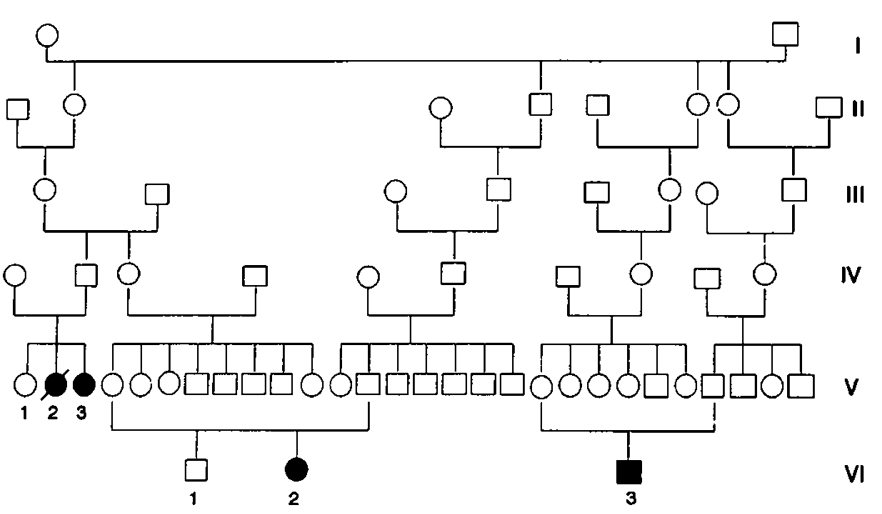

Figure 1. Pedigree of the children with IGHD type IA. Squares represent males, and circles females. The affected individuals are indicated by black symbols. The girl V-2 died at 4 mo of age of sudden infant death syndrome. The parents were heterozygous for the deletion.

tics at birth and at diagnosis are reported in Table 1. At 6 mo of age [length $49 \mathrm{~cm}$ ( $-7 \mathrm{SD}$ score), height velocity 15 $\mathrm{cm} / \mathrm{y}$ ], she was started on $\mathrm{r}-\mathrm{hGH}$ therapy (3 IU/wk, divided in three doses) (Saizen, Serono, Rome, Italy). At that time no anti-hGH antibodies were detected. After 1 mo of therapy, height velocity had increased to $31.2 \mathrm{~cm} / \mathrm{y}$ (length $52 \mathrm{~cm},-6 \mathrm{SD}$ score) but dropped to $14 \mathrm{~cm} / \mathrm{y}$ at 11 mo of age (length $56.2 \mathrm{~cm},-6.7 \mathrm{SD}$ score). For that reason, hGH dosage was increased to $4 \mathrm{IU} / \mathrm{wk}$ with no major improvements. At $1.3 \mathrm{y}$ of age, anti-hGH antibodies were detected with a binding capacity of $75.04 \mathrm{mg} / \mathrm{L}$ and binding affinity of $0.445 \times 10 \mathrm{M}$. At her last follow-up visit, at $1.7 \mathrm{y}$ of age, her length was $62.3 \mathrm{~cm}(-6.6 \mathrm{SD}$ score) and weight $6330 \mathrm{~g}$. The patient is now waiting to be included in an IGF-I therapeutic trial.

Subject VI-1. The boy was born at term in 1980 after a normal pregnancy. He developed without any problem and is normal for age and sex.

Patient VI-2. The patient, a girl, was born in 1983 by vaginal delivery to a 22 -y-old woman. In Table 1 , her main clinical and hormonal characteristics are reported. $\mathrm{r}-\mathrm{GH}$ treatment (Saizen, Serono) (4 IU/wk, divided in three doses) was started at $3.2 \mathrm{y}$ of age and led to an increase in growth rate from $3.7 \mathrm{~cm} / \mathrm{y}$ to $16.8 \mathrm{~cm} / \mathrm{y}$ during the first year of therapy. In the following $5 \mathrm{y}$, height velocity was maintained at an average rate of $7 \mathrm{~cm} / \mathrm{y}$ with a r-hGH dosage adjusted to approximately $15 \mathrm{IU} / \mathrm{m}^{2}$.

Table 1. Main clinical and hormonal characteristics of patients at birth and at diagnosis*

\begin{tabular}{|c|c|c|c|}
\hline Patient (sex) & $V-3(F)$ & $\mathrm{VI}-2(\mathrm{~F})$ & $\mathrm{VI}-3(\mathrm{M})$ \\
\hline Mean parental height $(\mathrm{cm})$ & 164.5 & 155.5 & 157.3 \\
\hline Gestational age (wk) & 33 & 39 & 39 \\
\hline Length at birth $(\mathrm{cm})$ & & 45 & 45 \\
\hline Weight at birth (g) & 1.470 & 2.300 & 2.700 \\
\hline Age at diagnosis $(y)$ & 0.25 & 3.16 & 4.16 \\
\hline Height at diagnosis (cm) (HSDS) & $44.5(-6.7)$ & $65.6(-7)$ & $76.3(-5.8)$ \\
\hline Bone age at diagnosis $(y)$ & & 1 & 0.75 \\
\hline Serum $G H$ peak levels after insulin, arginine, or clonidine stimulation $(\mu \mathrm{g} / \mathrm{L})$ & $<0.02$ & $<0.02$ & $<0.02$ \\
\hline Serum GH peak levels after $G H-R H$ stimulation $(\mu \mathrm{g} / \mathrm{L})$ & $<0.02$ & $<0.02$ & $<0.02$ \\
\hline Baseline IGF-I serum levels (ng/mL) & $<60$ & $<60$ & $<60$ \\
\hline Baseline and GH-RH-stimulated placental lactogen serum levels $(\mu \mathrm{g} / \mathrm{mL})$ & $<0.5$ & $<0.5$ & $<0.05$ \\
\hline
\end{tabular}

\footnotetext{
* HSDS, height standard deviation score; GH-RH, GH releasing hormone.
} 
Anti-hGH antibodies were detected shortly after the beginning of treatment but significantly declined thereafter and remained low throughout treatment with a binding capacity $<0.5 \mathrm{mg} / \mathrm{L}$ (Fig. 2). At the last follow-up visit (chronologic age $9.9 \mathrm{y}$ ), the patient's height was $124.7 \mathrm{~cm}$ (-1.4 SD score), weight $25.5 \mathrm{~kg}$, Tanner stage II, and bone age $10.5 \mathrm{y}$; the anti-hGH antibody titer was 1:100.

Patient VI-3. The child, a boy, was born in 1986 after a normal pregnancy and labor via spontaneous vaginal delivery. Birth weight and length are reported in Table 1. His childhood and infancy were significant for poor dietary intake, and the child has a history of seizure at 1.5 $y$ after a prolonged period of fasting.

Growth retardation became evident during the first year of life, and the boy was referred to the hospital of his hometown at $2.5 \mathrm{y}$ of age for failure to thrive. The diagnosis of hGH deficiency was made based on abnormal responses of hGH blood levels after arginine and glucagone stimulations (hGH response to pharmacologic stimulation $<10 \mu \mathrm{g} / \mathrm{L}$, as reported in his records). r-hGH treatment was given (Humatrope, Lilly, Indianapolis, IN) in a dose of $12 \mathrm{IU} / \mathrm{m}^{2}$, divided into three injections per week. Unfortunately, no records of the patient's height before or during the $1 \frac{1 / 2}{y}$ of treatment are available.

The patient was referred to our clinic in 1990 while still on hGH treatment. His main clinical and hormonal characteristics at that time are reported in Table 1. Significant anti-hGH antibody titers (1:50 000 at specific binding

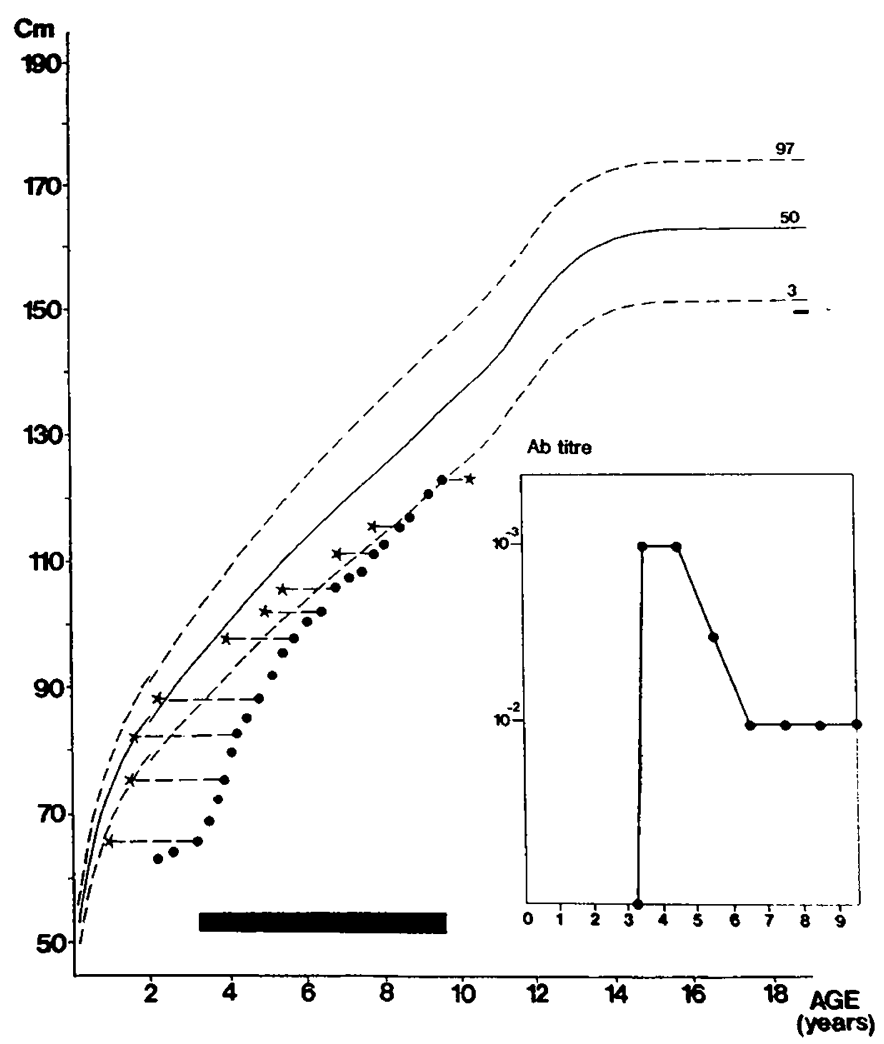

Figure 2. Heights $(\bullet)$, bone ages ( $\star$ ), and antibody titers (Ab titre) at $50 \%$ specific binding of patient VI-2 during treatment with $\mathrm{r}-\mathrm{hGH}$ (black bar).
$50 \%$ ) were detected in his serum. Methionyl r-hGH (metr-hGH, Somatonorm, Kabi-Pharmacia, Stockholm, Sweden; $16 \mathrm{IU} / \mathrm{m}^{2}$, divided in four weekly doses) was substituted for methionyl-free r-hGH, similar to the one used in both of the other patients, based on the possibility that the methionine molecule bound to the $\mathrm{N}$-terminal portion of the molecule, which is the most antigenic, might prevent antibody formation. This was not the case, as indicated by the very poor growth response of the patient in the following year of treatment (height velocity $2 \mathrm{~cm} / \mathrm{y}$ ). At the age of $6 \mathrm{y}$, he was included in an experimental therapeutic trial with recombinant IGF-I coordinated by Dr. Louis Underwood at the University of North Carolina in Chapel Hill and had excellent results in terms of growth response (14).

\section{Measurements}

Supine length and standing height were measured with a supine measuring table and a wall-mounted stadiometer (Harpenden and Holtain Ltd., Crymmych, UK). SD scores for height were calculated based on the data of Tanner et al. (15). Bone ages were determined using the standards of Greulich and Pyle (16).

Serum hGH, IGF-I, and placental lactogen concentrations were measured by RIA (Nichols Institute Diagnostics, San Juan Capistrano, CA, and Biodata, Rome, Italy).

Anti-hGH antibody titers were determined as previously described (17). An antibody titer was defined as the plasma dilution that bound $50 \%$ of hGH tracer. Binding capacities and affinity constants were determined by Scatchard analysis using the preparation 80/505 (International Reference Preparation for hGH) as standard.

\section{Genetic Analyses}

Restriction endonuclease analysis. Aliquots of highmolecular-weight nuclear DNA isolated from family members were digested with appropriate restriction endonucleases under conditions specified by the suppliers. The digests were subjected to electrophoresis in $0.8 \%$ (wt/vol) agarose gels. The DNA fragments were then transferred to nitrocellulose membranes and hybridized with a GH-1 cDNA probe (18) or a 1.1-kb Eco RI-SstIderived genomic fragment that lies downstream from GH-1 (8). The filters were washed and autoradiographed as previously described (10).

DNA sequence analysis. One set of primers, S1-AS1, was used in DNA sequencing experiments. Primer S1 (TGAAATCGAAGAAAATAATAC), which is located 5' to GH-1 at position 3837-58, shows some divergences with the corresponding sequences that lie $5^{\prime}$ to CS-A and CS-B (77 and 73\% homology, respectively). The antisense primer AS1 (CCAGAGACCAGGAACATTCA) corresponds to a sequence found within the first intron of both the CS-A and CS-B genes. PCR amplification and sequencing reactions were performed as previously described (19). 


\section{RESULTS}

Therapy with $\mathrm{r}-\mathrm{hGH}$ resulted in the prompt appearance of anti-hGH antibodies in all three patients. However, although the antibody titers in patients V-3 and VI-3 remained high after a variable period of time on therapy and were accompanied by an arrest in the growthpromoting effect of r-hGH, patient VI-2's antibody titer was low from the beginning and decreased further during the first year of therapy (Fig. 2). Moreover, the latter patient showed an excellent and sustained growth response to exogenous r-hGH (Fig. 2). She is now entering the seventh year of treatment, her height has reached the third percentile, and she has a predicted height of 149.5 $\mathrm{cm}$ in accordance with the target height.

Restriction endonuclease analysis demonstrated that the cause of hGH deficiency was the deletion of a large portion of the hGH gene cluster. When normal genomic DNA is digested with BamHI, six GH cDNA hybridizing fragments are obtained, ranging in size from 1.1 to $8.3 \mathrm{~kb}$. The GH-1 gene is contained in a 3.8-kb fragment, the $\mathrm{GH}-2$ lies in two pieces that are 1.1 and $2.9 \mathrm{~kb}$ in size, and the CS-L-, CS-A-, and CS-B-containing fragments are $8.3,5.3$, and $6.7 \mathrm{~kb}$, respectively. Analysis of patient VI-2's DNA revealed that only the $6.7-\mathrm{kb}$ fragment was present (Fig. 3). Similar results were obtained with DNA from the other two affected patients. The absence of the other fragments was associated with a deletion that removed the GH-1 gene, causing the GH deficiency, and four other genes, leaving intact the most $3^{\prime}$ sequence, i.e. the CS-B gene. To map the deletion breakpoints, the subjects' DNA was digested with EcoRI and hybridized with an EcoRI-SstI genomic probe. This DNA piece is part of the 4.7-kb fragment located $5^{\prime}$ to the GH-1 genecontaining fragment and contains a repeated motif that also hybridizes both to the 4.9-kb EcoRI fragment located

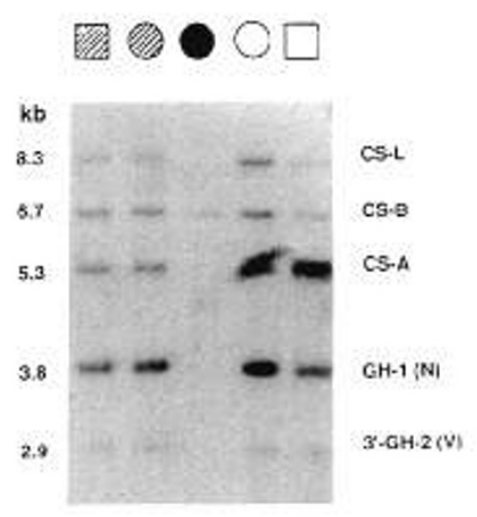

Bam Ht
Eco PI

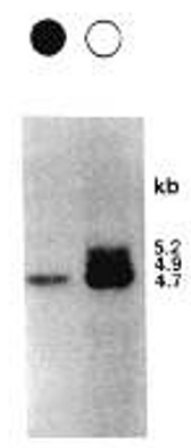

Figure 3. Autoradiograms of DNA from a normal subject and a normal sister (V-1; open symbols), an affected girl (V-3; black symbol), and the heterozygous mother and father (hatched symbols) after restriction endonuclease digestion with $\mathrm{Bam} \mathrm{HI}$ hybridized to a GH cDNA probe (left) and EcoRI hybridized to a genomic EcoRI-SstI probe (right). Squares represent males, and circles females. Fragment sizes in kilobases are indicated at the margins. between the GH-1 and CS-L genes and to the 5.2 EcoRI fragment $5^{\prime}$ to the CS-B gene. In normal subjects, three bands of $4.7,4.9$, and $5.2 \mathrm{~kb}$ are observed. In the patients' DNA, only the 4.7-kb band was detected (Fig. 3). This places the deletion $5^{\prime}$ breakpoint on the $3^{\prime}$ side of the 4.7-kb EcoRI fragment.

PCR amplification between two sequences located on each side of the deletion breakpoint (primers S1-AS1) yielded a 1563-bp DNA fragment in the affected children and their parents, in contrast to normal controls, where no PCR product was seen. The abnormal product seen in the patients is composed of three parts: the first 1287 nucleotides correspond to the $5^{\prime}$ sequence of the GH-1 (from nucleotide 3837 to 5125 ), the next six bases are common to the $5^{\prime}$ side of both the GH-1 and CS-B genes, and the remaining residues are specific to the CS-B gene sequence (from nucleotide 50200 to 50 468) (Fig. 4). This places the deletion breakpoint within nucleotides 5125 to 5130 on the $5^{\prime}$ side and within nucleotides 50194 to 50199 on the $3^{\prime}$ side of the cluster and indicates that the regulatory sequences located upstream to the TATA box of the mutant CS-B gene belong to the GH-1 gene.

\section{DISCUSSION}

The patients reported in this paper fulfilled most of the criteria for IGHD type IA, as outlined by Illig et al. (4). In fact, all of them had short body length at birth, early and severe growth retardation, and typical facial appearance. However, they differed from each other in their anti-hGH antibody production and, consequently, their growth response to exogenous hGH. The oldest girl (VI2 ), in fact, is now entering the seventh year of treatment with $\mathrm{r}-\mathrm{hGH}$ and has maintained a low anti-hGH antibody titer and a satisfactory height velocity, whereas the other

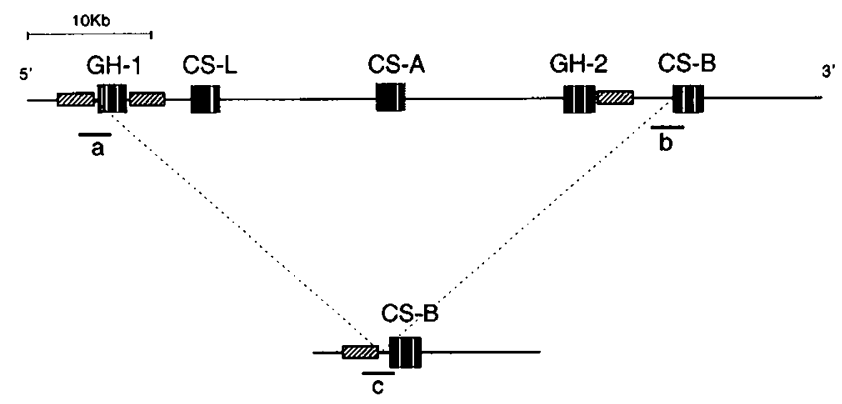

a AA-CAGTGGGAGAGAAGGGCCAG-GTATAAAAAGGGCCACAAGAGACCAGCTCA c AA-CAGTGGGagAGAGGGCCAGGGATAAAAAGGGCCACAAGAGACCGGTCT b AagCAgGGagagagAaCTGGCCAGGGTATAAAAAGGGCCACAAGAGACCGGCTCT

Figure 4. Schematic representation of the large deletion that removed the GH-1, CS-L, CS-A, and GH-2 gene sequences and left intact the $\mathrm{CS}-\mathrm{B}$ gene. The hatched rectangles indicate the location of the three homologous EcoRI fragments recognized by the $1.1-\mathrm{kb}$ genomic probe. The resulting fusion fragment obtained is shown above the sequence alignments. $a$, Part of the GH- 1 gene promoter sequence containing the TATA box. $b$, Part of the CS-B promoter sequence, aligned with $a$. $c$, Mutant CS-B promoter sequence, resulting from a fusion between sequences $a$ and $b$, the breakpoint being located within the six nucleotides contained in the stippled box. 
two children had the typical strong anabolic response to an initial course of $\mathrm{r}-\mathrm{hGH}$ rapidly followed by the appearance of high-titer anti-hGH antibodies with growth arrest.

Birth size in patients with IGHD type IA is extremely heterogeneous and does not seem to correlate with the deletion size, ruling out, together with other clinical and experimental evidence (20-23), a role for $\mathrm{GH}$ in fetal growth. The low birth weights and lengths of the patients that we studied cannot be related to the absence of the other genes of the cluster either, because patients with the same deletion previously reported (11) had normal birth weights. Moreover, the poor socioeconomic status of the family and the heavy smoking of the mothers have undoubtedly contributed to the small neonatal size.

A great phenotypic heterogeneity with respect to antibody formation has been reported in several cases of IGHD type IA described previously (13, 24-27). However, the deletion of the hGH-CS gene cluster described in one of the patients of the present study is, to our knowledge, the largest ever reported not associated with the development of anti-hGH antibodies in sufficient titer to inhibit growth. In fact, to date, each of the patients with large gene deletions reported previously (10-12) developed high-titer anti-hGH antibodies associated with immune intolerance to $\mathrm{r}-\mathrm{hGH}$ replacement. Among these latter patients are those from the Turkish family carrying a 45-kb deletion similar to the one described in the present study (11). However, because the determination of the deletion breakpoints of the mutation reported previously (11) was based on restriction endonuclease mapping only, the crossover site has not been accurately mapped within the 300 bp 5' to the GH-1 gene (and to the CS-B gene). Nevertheless, given the Mediterranean extraction of the patients from both families (Italian and Turkish), the mutant alleles may have a common origin.

The reasons for the different susceptibility to antibody formation in patients with IGHD type IA have yet to be clarified. A possible explanation is that the deletions may differ with regard to antenatal production of peptides related to hGH and, thus, to induction of immune response (27). Alternatively, factors other than the gene deletion per se, such as different associations of the exogenous hGH with HLA-D molecules on the surface of the antigen-presenting cells (28) or different combinations of immune response genes, may contribute to this phenotypic heterogeneity.

The only gene spared by the deletion in our patients is the CS-B gene, which is responsible, as is the CS-A gene, for the production of $\mathrm{CS}$, also known as placental lactogen, by the placenta. In addition to being in proximity to the GH-1 promoter, the CS-B gene has lost the "P" region that is common to $5^{\prime}$ regions for the placentally expressed genes and is recognized by an inhibitory transacting factor present in pituitary nuclei (29). For this reason, human placental lactogen serum concentrations were measured at baseline and after GH-RH stimulation, but no detectable levels were found in either of the patients, ruling out the possibility that approximation of
$\mathrm{CS}-\mathrm{B}$ to the regulatory elements for $\mathrm{GH}-1$ could result in regulated somatotrophic expression of CS-B.

To summarize, we describe an Italian family with a 45-kb gene deletion within the hGH-CS gene cluster, encompassing the GH-1, CS-L, CS-A, and GH-2 genes. Two of the affected children developed high-titer antihGH antibodies with secondary growth arrest, whereas the third one maintained normal growth on $\mathrm{hGH}$ replacement therapy in the presence of very low-titer antibodies. Therefore, it can be concluded that the immune response to exogenous hGH is not related to the size of the deletion and the search for hGH gene deletion should not be confined to patients with antibody formation and subnormal growth responses, but all patients with severe growth retardation should be screened for the presence of $\mathrm{hGH}$ gene deletion.

\section{REFERENCES}

1. Rona RJ, Tanner JM 1977 Aetiology of idiopathic growth hormone deficiency in England and Wales. Arch Dis Child 52:197-208

2. Vimpani GV, Vimpani AF, Lindgard A, Farquhar JW 1977 Prevalence of severe growth hormone deficiency. Br Med J 2:427-430

3. Phillips III JA, Ferrandez A, Frisch H, Illig R, Zuppinger K 1986 Defects of growth hormone genes. Clinical syndromes. In: Raiti S, Tolman RA (eds) Human Growth Hormone. Plenum, New York, pp 211-226

4. Illig R, Prader A, Ferrandez A, Zachmann M 1971 Hereditary prenatal growth hormone deficiency with increased tendency to growth hormone antibody formation (A-type isolated growth hormone deficiency). Acta Paediatr Scand Suppl 60:607 (abstr)

5. Chen EY, Liao YC, Smith DH, Barrera-Saldana HA, Gelinas RE, Seeburg PH 1989 The human growth hormone locus: nucleotide sequence, biology, and evolution. Genomics 4:479-497

6. Frankenne F, Scippo ML, Van Beeumen J, Igout A, Hennen G 1990 Identification of placental human growth hormone as the growth hormone-V gene expression product. J Clin Endocrinol Metab 71:15-18

7. Barrera-Saldana HA, Seeburg PH, Saunders GF 1983 Two structurally different genes produce the same human placental lactogen hormone. J Biol Chem 258:3787-3793

8. Vnencak-Jones CL, Phillips III JA, Chen EY, Seeburg PH 1988 Molecular basis of human growth hormone gene deletions. Proc Natl Acad Sci USA 85:5615-5619

9. Kamijo T, Phillips III JA 1992 Detection of molecular heterogeneity in GH-1 gene deletions by analysis of polymerase chain reaction amplification products. J Clin Endocrinol Metab 74:786-789

10. Goossens M, Brauner R, Czernichow P, Duquesnoy P, Rappaport R 1986 Isolated growth hormone $(\mathrm{GH})$ deficiency type IA associated with a double deletion in the human GH gene cluster. J Clin Endocrinol Metab 62:712-716

11. Akinci A, Kanaka C, Eblé A, Akar N, Vidinlisan S, Mullis PE 1992 Isolated growth hormone $(\mathrm{GH})$ deficiency type IA associated with a 45-kilobase gene deletion within the human GH gene cluster. J Clin Endocrinol Metab 75:437441

12. Baroncini C, Baldazzi L, Marchetti G, Capelli M, Cacciari E, Bernardi F 1993 Deletion breakpoints in a 32 bp perfect repeat located $45.1 \mathrm{~kb}$ apart in the human growth hormone gene cluster. Hum Mol Genet 2:2151-2153

13. Rivarola MA, Phillips III JA, Migeon CJ, Heinrich JJ, Hjelle BJ 1984 Phenotypic heterogeneity in familial isolated growth hormone deficiency type IA. J Clin Endocrinol Metab 59:34-40

14. Backeljauw PF, Underwood LE 1993 Effects of prolonged IGF-I treatment in children with growth hormone insensitivity syndrome (GHIS). Pediatr Res 33:S56(abstr)

15. Tanner JM, Whitehouse RH, Takaishi M 1966 Standards from birth to maturity for height, weight, height velocity, and weight velocity: British children, 1965. Arch Dis Child 41:613-635

16. Greulich WW, Pyle SI 1959 Radiographic Atlas of the Skeletal Development of the Hand and Wrist, 2nd Ed. Stanford University Press, Stanford, CA

17. Illig R 1970 Growth hormone antibodies in patients treated with differen preparations of human growth hormone $(\mathrm{hGH})$. J Clin Endocrinol Metab 31:679-688

18. Roskam WG, Rougeon F 1979 Molecular cloning and nucleotide sequence of the human growth hormone structural gene. Nucleic Acid Res 7:305-320

19. Gyllensten UB, Erlich HA 1988 Generation of single-strand DNA by the polymerase chain reaction and its application to direct sequencing of the HLA-DQA locus. Proc Natl Acad Sci USA 85:7652-7656

20. Grunt JA, Reynolds DW 1970 Insulin blood sugar and growth hormone levels in an anencephalic infant before and after intravenous administration of glucose. Pediatrics 76:112-116 
21. Laron Z, Pertzelan A, Karp M, Kowaldo-Silbergeld A, Daughaday WH 1971 Administration of growth hormone to patients with familial dwarfism with high immunoreactive growth hormone: measurement of sulfation factor, metabolic and linear growth responses. J Clin Endocrinol Metab 33:332-342

22. Chez RA, Hutchinson DL, Salazar H, Mintz DH 1970 Some effects of fetal and maternal hypophysectomy in pregnancy. Am J Obstet Gynecol 208:643-650

23. Hill DJ, Freemark M, Strain AJ, Handwerger S, Milner RDG 1988 Placental lactogen and growth hormone receptors in human fetal tissues: relationship to fetal plasma human placental lactogen concentrations and fetal growth. J Clin Endocrinol Metab 66:1283-1290

24. Braga S, Phillips III JA, Joss E, Schwarz H, Zuppinger K 1986 Familial growth hormone deficiency resulting from a $7.6 \mathrm{~kb}$ deletion within the growth hormone gene cluster. Am J Med Genet 25:443-452

25. Hauffa BP, Illig R, Torresani T, Stolecke H, Phillips III JA 1989 Discordant immune and growth response to pituitary and biosynthetic growth hormone in siblings with isolated growth hormone deficiency type IA. Acta Endocrinol (Copenh) 121:609-614

26. De Luca F, Duquesnoy P, Arrigo T, Lombardo F, Goossens M 1992 Very late immune response to growth hormone $(\mathrm{GH})$ therapy in an infant with $\mathrm{GH}-\mathrm{N}$ gene deletion. Acta Paediatr Scand 81:730

27. Laron Z, Kelijman M, Pertzelan A, Keret R, Shoffner JM, Parks JS 1985 Human growth hormone gene deletion without antibody formation or growth arrest during treatment: a new disease entity? Isr J Med Sci 21:999-1006

28. Andersson R 1986 Immunological aspects of human growth hormone. Acta Paediatr Scand Suppl 325:48-54

29. Nachtigal MW, Nickel BE, Cattini PA 1993 Pituitary-specific repression of placental members of the human growth hormone gene family. J Biol Chem 268:8473-8479

\section{Announcement}

\section{The Society for Adolescent Medicine Annual Meeting}

The Society for Adolescent Medicine, a multidisciplinary organization, will hold its annual meeting in Vancouver, British Columbia, on March 22-25, 1995, at the Vancouver Trade and Convention Center with the Waterfront Hotel as host hotel. The theme for the meeting will be "International Perspectives on Adolescent Health." In addition to addressing this topic, the meeting will present new material on a broad range of issues important to adolescent physical and emotional health, including AIDS and HIV medical management, teenage sexuality, eating disorders, depression, and risk-taking behaviors, which encompass drug and alcohol use and abuse. Meeting presentations include 3-hour clinically oriented workshops, luncheon seminars, and scientific research paper presentations and poster sessions, as well as the prestigious Gallagher Lecture Series. CME/ CEUs are available.

For further information, contact the Society for Adolescent Medicine, Suite 120, 19401 E. 40 Highway, Independence, MO 64055, (816) 795-8336. 